Litteratur

1. Hjellvik V, Mahic M, Tverdal A. Utdanning og legemiddelbruk. Tidsskr Nor Legeforen 2012; 132: 2166-70.

2. Slørdal L. Høna, egget og forskjellene. Tidsskr Nor Legeforen 2012; 132: 2142 .

3. Getz L, Kirkengen AL, Ulvestad E. Menneskets biologi - mettet med erfaring Tidsskr Nor Legeforen 2011; 131: 683-7.

Publisert som rask respons i nettutgaven 6.11. 2012

\section{Uberettiget kritikk}

Tusen takk for anmeldelsen av Elektrolyttveileder i Tidsskriftet nr. 19/2012 (1). Vi vil gjerne knytte noen kommentarer til den. Det står at heftet er gratis, noe som ikke stemmer helt. Den er tilgjengelig på helsebiblioteket.no, men den trykte versjonen koster $\mathrm{kr} 45, \mathrm{kr} 35$ dersom man bestiller 50 eller flere eksemplarer. Dette går til trykk og forsendelse. Vi informerte om dette i e-post til Tidsskriftet da vi ba om en omtale av veilederen.

Vi synes at en del av kritikken mot veilederen er uberettiget. Hans Flaatten skriver at omtale av den viktigste elektrolyttforstyrrelsen, nemlig hypokalemi, mangler. Under avsnittet om kalium står det imidlertid om anbefalt dosering, maksimal konsentrasjon, maksimal infusjonshastighet, forsiktighetsregler og monitorering. Videre skriver han at det bør stå anbefalt hastighet for korrigering av hyponatremi. Dette står under avsnittet om natrium.

Flaatten skriver at under omtale av kalsiumklorid står en indikasjon som ikke har med hyperkalsemi eller hypokalsemi å gjøre, nemlig hypokalemi. Dette stemmer ikke, da vi har tatt med dosering av kalsiumklorid ved hyperkalemi, noe som er en viktig del av akuttbehandlingen av pasienter med alvorlig hyperkalemi. Vi anså det som viktig å ha med dette, da vi omtaler bruk av kalsiumklorid under dette avsnittet. Det at dette burde være tatt med under et eget avsnitt om hyperkalemi er vi helt enige i, og dette vil komme i neste utgave.

Tidsskriftet ble informert om at neste utgave av veilederen kommer til å inneholde mer detaljerte prosedyrer for samtlige elektrolyttforstyrrelser. Denne opplysningen synes ikke å ha blitt brakt videre til Flaatten, hvilket var litt uheldig. Punktene over kan gi feilaktig inntrykk av veilederen for lesere som ikke er kjent med den.

Vi takker igjen for omtalen av Elektrolyttveileder. Hvis Tidsskriftet velger å omtale 2. utgave når den kommer, håper vi at dere vil sørge for at omtalen er mer nøyaktig.

\section{Kiarash Tazmini}

kiakol3@gmail.com

Tonje T. Johansen

Kiarash Tazmini (f. 1976) er lege ved Diakonhjemmet Sykehus og stipendiat ved Diakonhjemmet Sykehus og Institutt for eksperimentell medisinsk forskning (IEMF), Oslo universitetssykehus, Ullevål. Han er en av forfatterne av veilederen.

Ingen oppgitte interessekonflikter

Tonje T. Johansen (f. 1970) er cand.pharm., klinisk farmasøyt ved Diakonhjemmet sykehusapotek og mastergradsstudent i erfaringsbasert klinisk farmasi ved Universitetet i Oslo. Hun er den andre forfatteren.

Ingen oppgitte interessekonflikter

\section{Litteratur}

1. Flaatten T. Væske- og elektrolyttbehandling - en god veileder. Anmeldelse av: Tazmini K, Johansen TT. Elektrolyttveileder. Tidsskr Nor Legeforen 2012; 132 2196.

\section{Evolusjonær tilpasning og kronisk utmattelsessyndrom}

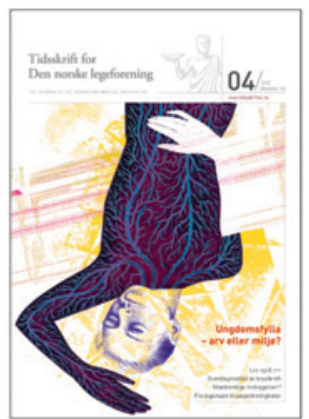

Rune Karlson mener i Tidsskriftet nr. 4/ 2012 at kronisk utmattelsessyndrom er en tilpasning i evolusjonær forstand som har fungert som en adaptiv barriere mot kollaps i fortiden (1). Jeg mener det er mer sannsynlig at sentrale årsaker til kronisk utmattelsessyndrom er nye miljøfaktorer som ikke eller i langt mindre grad var til stede $\mathrm{i}$ fortidsmiljøet og som vi derfor verken tåler godt eller har effektive forsvarsmekanismer mot (2). Når sykdomstilstanden først er utløst av infeksjoner, vaksiner eller dramatiske livshendelser, vil slike evolusjonært sett nye faktorer bidra til å vedlikeholde den. Dette kan for eksempel være endringer i kostholdet eller eksponering for kjemiske og/eller fysisk miljøfaktorer. Disse bidrar til at personen forblir i en alvorlig kronisk sykdoms- og stresstilstand (2).

Karlson svarer med at forutsetningen for at kronisk utmattelsessyndrom kan være en tilpasning, er at personer med omsorgsansvar blir vernet av gruppen de tilhører, selv når de er inne i en langvarig og plagsom utmattelse. Hans premiss for å forstå kronisk utmattelsessyndrom som en adaptiv barriere mot kollaps er at mennesker kan overleve i lange perioder uten optimalt overskudd og årvåkenhet fordi vi lever i gjensidig forpliktende og beskyttende grupper (3).

Et slikt argument kan brukes for enhver sykdom. Det har lenge vært karakteristisk for vår art at en storfamilie, eventuelt støttet av et nettverk av ubeslektede individer, tar del i omsorgen for syke mennesker, eventuelt deres barn. Det er derfor ikke noe som spesifikt har med kronisk utmattelsessyndrom å gjøre.

Mitt hovedpoeng er derfor at kronisk utmattelsessyndrom primært skyldes nyere miljøfaktorer. Da er det ikke noe behov for å konstruere et adaptivt scenario for hvorfor en slik tilstand kan ha vært fordelaktig i fortidsmiljøet, slik Karlson har gjort. Hvis fremtidig forskning finner bred støtte for den typen årsaksfaktorer jeg har skissert, har den samtidig underminert Karlsons adaptive hypotese. Tilstander som skyldes moderne miljøfaktorer, trenger ingen adaptive hypoteser om fordelaktige effekter i fortidsmiljøet. Så vidt jeg vet, foreligger det ingen forskning som underbygger at denne tilstanden er påvist eller utbredt hos mennesker som i moderne tid har en livsstil som jegere og sankere. Den typen livsstil brukes ofte som en (forenklet) modell for hvordan fortidens liv har vært $\mathrm{i}$ lange tidsrom før jordbruket oppsto.

Iver Mysterud

mysterud@bio.uio.no

Iver Mysterud (f. 1966) er dr.philos. i biologi. Han er tilknyttet Biologisk institutt ved Universitetet i Oslo som forsker/foreleser og er fagredaktør i helsemagasinet VOF.

Ingen oppgitte interessekonflikter.

\section{Litteratur}

1. Karlson R. En evolusjonær forståelse av kronisk utmattelsessyndrom. Tidsskr Nor Legeforen 2012; 132: 400-1.

2. Mysterud I. Kronisk utmattelsessyndrom og evolusjon. Tidsskr Nor Legeforen 2012; 132: 1060

3. Karlson R. Kronisk utmattelsessyndrom og evolusjonær tilpasning. Tidsskr Nor Legeforen 2012; 132: 1317

Publisert som rask respons i nettutgaven 7.8. 2012 